\title{
New population models help explain declines in the globally rare boreal felt lichen Erioderma pedicellatum in Newfoundland
}

\author{
R. Ian Goudie ${ }^{1, *}$, Christoph Scheidegger ${ }^{2}$, Claudia Hanel ${ }^{3}$, Anne Munier ${ }^{4}$, \\ Eugene Conway ${ }^{5}$
}

\footnotetext{
${ }^{1}$ LGL Limited Environmental Research Associates, 388 Kenmount Road, St. John's, Newfoundland and Labrador A1B 4A5, Canada

${ }^{2}$ Swiss Federal Institute for Forest, Snow and Landscape Research, WSL Zürcherstr. 111, 8903 Birmensdorf, Switzerland

${ }^{3}$ Department of Environment and Conservation, Endangered Species Branch, 117 Riverside Drive, PO Box 2007, Corner Brook, Newfoundland and Labrador A2H 7S1, Canada

${ }^{4}$ Centre for Non Timber Resources, Royal Roads University, 2005 Sooke Rd, Victoria, British Columbia V9B5Y2, Canada ${ }^{5}$ Newfoundland Lichen Education and Research Group, Box 16, Conception Harbour, Newfoundland and Labrador A0A1Z0, Canada
}

\begin{abstract}
A preliminary population model was developed for the boreal felt lichen Erioderma pedicellatum (Hue) P. M. Jørg. in Newfoundland using life stage data collected in eastern and south-central Newfoundland, Canada. This Critically Endangered epiphytic lichen displayed a life history strategy with high adult survival and low recruitment. Deterministic models in 6 mo to 1 yr intervals were generated, yielding similar results to the overall mean values for the $4 \mathrm{yr}$ of study in eastern Newfoundland. The populations of E. pedicellatum in Newfoundland are predicted by our models to be unsustainable because of adult mortality, and we attribute this problem to a decline in the forests of balsam fir Abies balsamea (Mill) that predominantly support this lichen. In eastern Newfoundland, thalli are located almost entirely on mature to over-mature balsam fir, and there is little regeneration because of heavy browsing by the introduced moose Alces alces population. The current and projected predictors indicate that habitat effects may be important in predicting future population size. An assessment of the stable stage distribution indicated that the current population has more juveniles and fewer apothecia-bearing thalli than projected, meaning the current population likely generated from a different set of survival and recruitment rates. The projected annual population growth rates calculated for $4 \mathrm{yr}$ indicated that populations are declining $(\lambda<1.0$, mean decline $\pm \mathrm{SD}=-0.175 \pm 0.079$ ) The elasticity values support the fact that the population growth rates are most sensitive to changes in the survival of necrotic (apothecia-bearing) cohorts. We suggest that conservation is best focused on the inventory and protection of old-growth forests important to this species, the reduction of the introduced moose population and the use of herbivore exclosures in specific core population areas.
\end{abstract}

KEY WORDS: Demography - Population model - Boreal felt lichen - Stable stage distribution · Elasticity analysis $\cdot$ Old-growth forests $\cdot$ Dispersal $\cdot$ Forest landscapes

Resale or republication not permitted without written consent of the publisher

\section{INTRODUCTION}

Many species of epiphytic lichens in eastern Canada occur only in natural forests, and old growth stands are especially important for some species (Cameron 2002, Cameron \& Neily 2008). Considerable controversy arises because of conflicts between industrial use of the forest and the need to maintain biodiversity (e.g. www.erioderma.com). At the landscape level, forest management tends to promote homogeneity, resulting in lichen communities that are less species rich than natural forests that have a diversity of ages and struc- 
tures including large patches with interior habitat (Richardson \& Cameron 2004). In clear-cuts, edge effects on epiphytic lichens are apparent (Rheault et al. 2003), and some species may not be effective at dispersing outside of intact old growth stands (Sillett et al. 2000). Stands surrounding clear-cuts may lack key microhabitat features for establishment of thalli because, in some cases, the cyanobacterial photobiont may distribute more widely than the lichen ascospores (Werth et al. 2006a, Scheidegger et al. 2007). Within stands, important components of heterogeneity include things such as remnant trees, crown closure and tree spacing that affect species' occurrences (Cameron 2002). Individual host trees, such as balsam fir Abies balsamea (Mill), may not live more than 120 yr and yet create stands that may be defined as old-growth forests in terms of their mites and insect diversity (Thompson et al. 2003).

The boreal felt lichen Erioderma pedicellatum (Hue) P. M. Jørg. is a conspicuous foliose lichen known from Scandinavia (Ahlner 1948, Holien et al. 1995, Tønsberg et al. 1996, Jørgensen 1990), Atlantic Canada, from Newfoundland to Nova Scotia and New Brunswick (Ahti \& Jørgensen 1971, Maass 1980, 1983), as well as Alaska (Nelson et al. 2009). Over the last $70 \mathrm{yr}$, the European population has decreased dramatically (Holien et al. 1995, Tønsberg et al. 1996, Scheidegger 1998) despite efforts to preserve the remaining populations. The extremely small European population of $E$. pedicellatum is mainly threatened by stochastic events such as the death of one of the very few host trees. In contrast, the population on the Canadian east coast is mainly threatened by habitat loss, degeneration and air pollution (Scheidegger 1998, 2003). The populations in New Brunswick and Nova Scotia have suffered an alarming reduction during the past few decades (Maass \& Yetman 2002), and key aspects of microsite selection have generally evaded accurate quantification; for example, recent habitat modeling in Nova Scotia resulted in accurate predictability of $7.1 \%$ (13 of 183 polygons) for occurrences (Cameron \& Neily 2008). As few as 70 to 100 individual thalli remain in these provinces. In Newfoundland, the species is still known from a number of sites, although many populations have disappeared since the first reports of this species in the 1970s (Ahti \& Jørgensen 1971, Maass 1980, Maass \& Yetman 2002, Keeping \& Hanel 2006). E. pedicellatum is currently listed in Newfoundland as a species of special concern by the federal Species At Risk Act and as vulnerable under the Newfoundland and Labrador Endangered Species Act. Approximately 8000 thalli have been discovered on insular Newfoundland over the past 2 decades, but monitored populations are declining rapidly (R. I. Goudie \& E. Conway unpubl. data).
Lichens offer challenges for population biology because individuals are composed of a fungus in association with either a unicellular green alga or a cyanobacterium. The functioning thallus may be considered an individual (Farrar 1974, Hill 1981, Nash 1996), but enumeration of individuals in the wild is made more difficult by the fact that regeneration can occur from fragments of thalli that are released from necrotic specimens of Erioderma pedicellatum. The demographic structure and dynamics of lichen populations are often not well understood (Fahselt 1996). Geographically defined clusters of thalli are often used as surrogates for populations in research studies (Werth et al. 2006b, 2007, Scheidegger et al. 1995, 2000, Scheidegger \& Werth 2009).

Our objective was to develop a system of classifying thalli into life stage cohorts that could be tracked over time in order to ascertain survival rates and transition probabilities. The purpose of this was to develop preliminary matrix population models, and to use elasticity matrices to assess which stages of the life cycle most influence population growth potential. From this information, future field efforts can be focused towards monitoring of these key life stages (Caswell 2001).

The current population of Erioderma pedicellatum is, in our view, limited by habitat availability and fragmentation, so we focused on deterministic analyses, that is, calculation of multiple transition matrices to assess seasonal and annual rates of survival. We recognize that demographic data collected over 4 yr also allow the development of a stochastic model.

\section{MATERIALS AND METHODS}

Life stage information was collected on Erioderma pedicellatum at Lockyer's Waters in eastern Newfoundland, from the fall to spring ('winter') and from the spring to fall ('summer') for 2005-2006, 2006-2007, 2007-2008 and 2008-2009. To broaden our demographic assessment we also included and integrated preliminary data from the Bay d'Espoir area in south-central Newfoundland from fall 2007 to fall 2008 (Fig. 1). Both sites are defined as wet boreal and occur within the Avalon forest and western forest ecoregions, respectively, which are predominated by balsam fir forests that receive sufficient precipitation and fog to ensure that fires are rare to nonexistent (Thompson et al. 2003).

The boreal felt lichen thalli were classified into 6 life stage cohorts, defined as follows:

(1) Juvenile 1 (J1): (generally $\leq 3 \mathrm{~mm}$ ), recruits thought to be generated by germination and lichenisation of diaspores detected since the previous interval (field visit). Note that for fall 2005 at Lockyer's Waters, Juvenile 1 was not differentiated from Juvenile 2. 


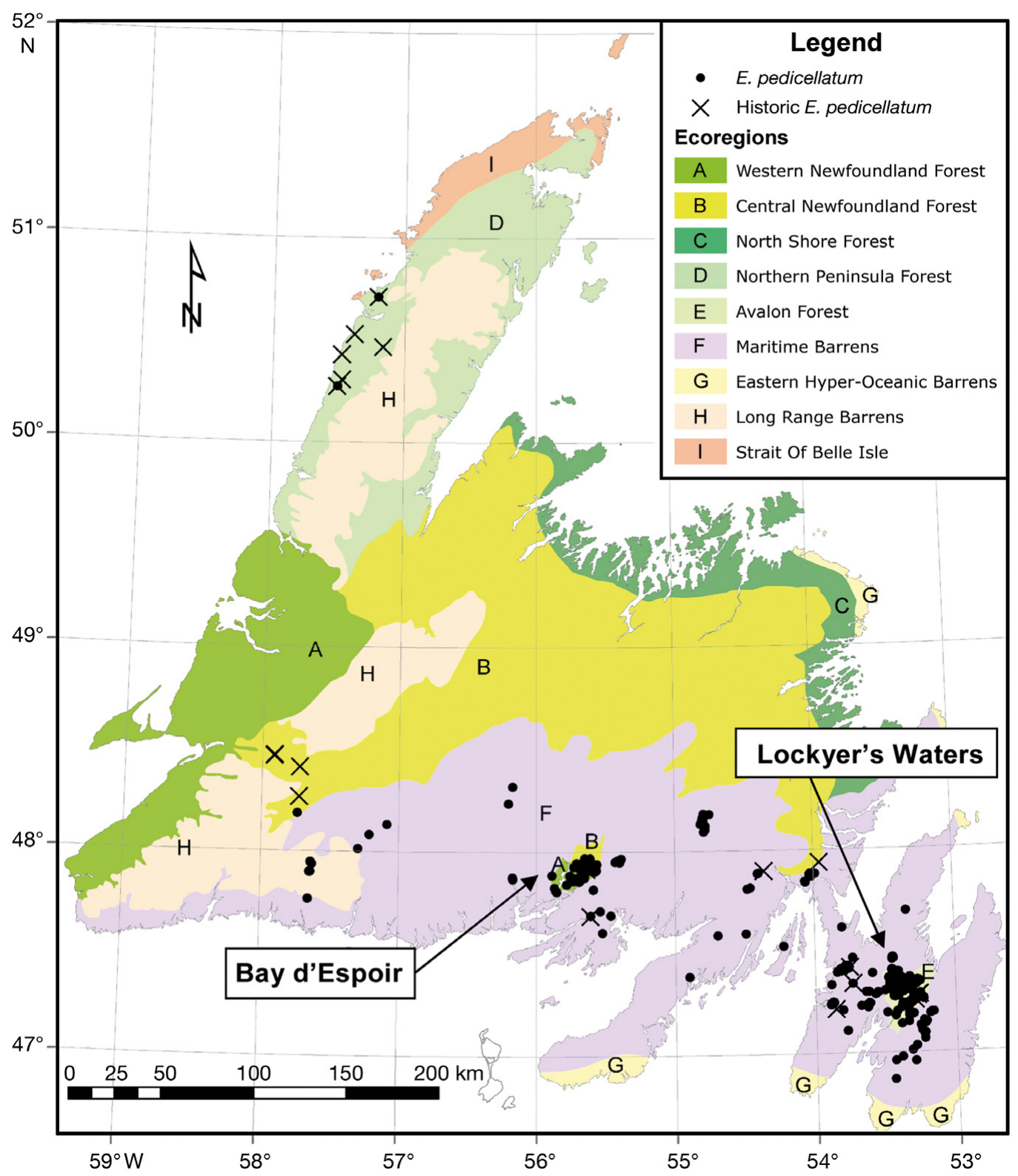

Fig. 1. Known range of Erioderma pedicellatum (boreal population) on the Island of Newfoundland as of March 2010 showing approximate locations of the Lockyer's Water and Bay d'Espoir study areas (source: Department of Environment and Conservation, NL)

(2) Juvenile 2 (J2): (generally $>3 \mathrm{~mm}$ ), recruits that lacked apothecia or primordial apothecia that are thought to have originated from thalli previously classified as Juvenile 1 or Juvenile 2. In some cases, juveniles in this class may arise from regenerating fragments of a necrotic thallus.

(3) Adults (A): healthy thalli, with apothecia or primordial apothecia, having no symptoms of necrosis (necrosis in a portion of a thallus was characterized by a yellowish or orange discolouration).

(4) Necrotic (N): thalli securely attached, with necrosis evident on at least one area of the thallus (the degree of necrosis was ranked as 1: $<25 \%$; 2 : $25-<50 \%$; $3: 50-75 \%$; and $4:>75 \%$ ).

(5) Necrotic loose (NL): thalli were no longer securely attached to the substrate (attachment was ranked as 1: $<25 \%$ attachment; 2: $25-50 \%$ attachment; 3: >50-75\% attachment; $4:>75 \%$ attachment; and 5: fully attached).

(6) Necrotic regenerating (NR): thalli displayed some degree of necrosis but with evidence of newly emerging growth generally along a leading edge of the thallus, and usually as clusters of small light greyish lobes. 
Dead thalli were those that had either disappeared since the previous interval (field visit) or had remained attached to the host but in a moribund state. Dead thalli lacked the characteristic light grey colour (when dry) or the dark green colour (when wet) of living thalli.

The life stage cohorts were arranged in a stagestructured cycle diagram that represents a number of nodes connected by arcs. This portrays the life cycle and helps to identify potential transitions, which can be assessed to see if they actually exist in the field (Caswell 2001) (Fig. 2). Paths indicate transitions between life stages and are called loops. When loops do not bypass other nodes they are called self-loops. To move from one life stage or node to another, an individual must survive. These paths and loops provided the parameters for the population matrix, which calculates the product of survival and the rate of change (transition) into a life stage (Leslie 1945, Caswell 2001). For Erioderma pedicellatum in our study area, we noted that most transitions occurred, although some were very infrequent.

A parameter matrix for projecting a preliminary population model was generated using the estimated survival $(\varnothing)$ and transition rates $(P)$ of life stages based on the field data for summer and winter intervals, and was analysed in Matlab ${ }^{\circledR}$. For example, in J1, if 20 of 25 thalli survived the interval (5 died), then $\varnothing=0.80$, and if 10 of these J1 transitioned to J2 during the same interval, then $P=0.50$, and, therefore, the value for the $\mathrm{J} 1$ to $\mathrm{J} 2$ parameter to include in the parameter matrix

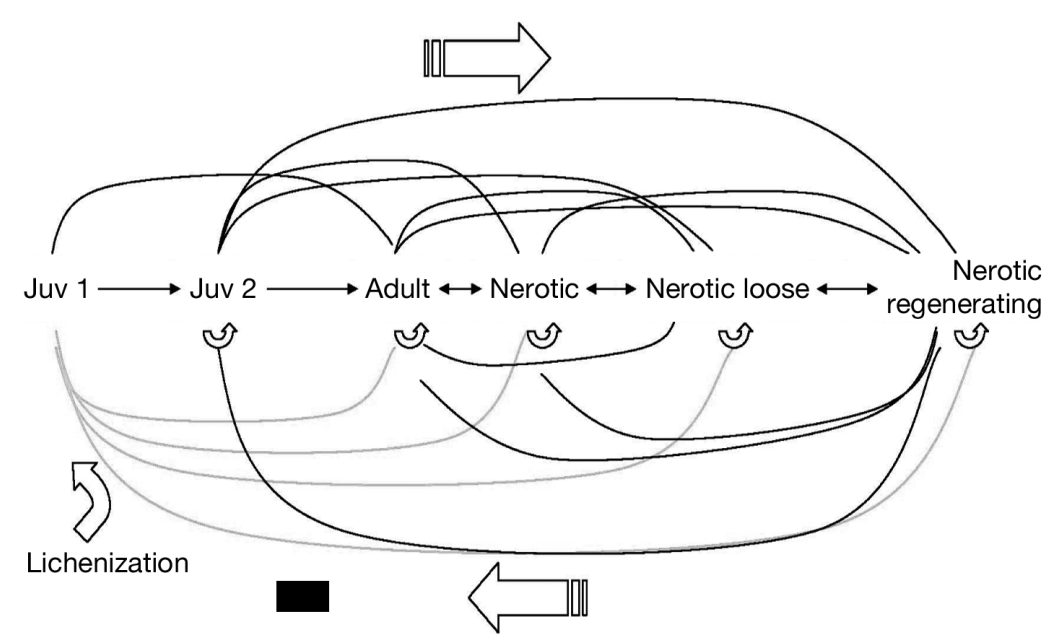

Fig. 2. Erioderma pedicellatum. Life cycle graph demonstrating the fecundity and possible transitions among life stage cohorts. Note that upper and lower loops are transitioning to the right and left, respectively, and grey lines represent fecundity vectors via sexual reproduction. During the study interval, thalli may survive and remain in the same life stage cohorts or transition to other cohorts (small, curved block arrows and lines, respectively). Apothecia-bearing thalli release fungal spores (grey lines) that on an appropriate bark substrate contact the cyanobacterium (Scytonema sp.), and lichenisation commences. The role of possible vectors in dispersal, and duration to achieve lichenisation and emergence as a juvenile thalli, are unknown would be $0.80 \times 0.50=0.40$. The populations were projected for 1 interval by multiplying the parameter matrix by the population vector, which is the number of individuals in each life stage at the beginning of the interval (Fig. 3). Annual population trajectories were generated by multiplying the summer and winter parameter matrices. The population growth rate for a year $(\lambda)$ was the dominant eigenvalue of this annual matrix, where 1.0 would indicate constant numbers (Caswell 2001). All season, annual projection and associated elasticity matrices are presented in the supplementary material (Tables S1 \& S2, see www.int-res.com/articles/ suppl/n013p181_supp.pdf). We present an overview of analyses for Lockyer's Waters by using the mean meter matrix. The stable stage distributions were by multiplying the initial population stages sient dynamics. We compared these projections to the actual proportions detected in each life stage in the field. Commencing in 2009, a stochastic model was developed in order to incorporate the seasonal and annual variability in demographic rates because some uthors have noted that deterministic analyses may ult in very different conclusions attributable to sampling variation and variation in environmental conditions (Fieberg \& Ellner 2001).

The effect of a proportional change in a life history trait was assessed by using Matlab ${ }^{\complement}$ to compute the elasticity matrix from the parameter matrix, and elasticity values for each life stage are interpreted as the effect on relative fitness $(\lambda)$ of a proportional change in a life stage parameter (Caswell 2001). The elasticity values can be considered partial regression coefficients of relative fitness $(\lambda)$ of a life stage while holding all other characters constant. Interpretations of elasticity values are relatively intuitive because this matrix sums to 1.0. Note that because the elasticities are obtained by multiplying each element in the stable stage distribution by each element in the reproductive value vector, each cell in the elasticity matrix is nonzero, even though corresponding cells in the original projection matrix have values of zero (McDonald \& Caswell 1993).

In order to run a preliminary matrix model for Erioderma pedicellatum, some basic assumptions were necessary. It was not possible to partition recruitment across the various adult life stages. Nor was it feasible to link apothecial abundance with lichen recruits, as the number of apothecia per thalli ranged from 
Parameter matrix $=S \times P$

$\left[\begin{array}{llllll}\mathbf{J 1 J 1} & \mathrm{J} 2 \mathrm{~J} 1 & \mathrm{AJ} 1 & \mathrm{NJ} 1 & \mathrm{NLJ1} & \mathrm{NRJ} 1 \\ \mathrm{~J} 1 \mathrm{~J} 2 & \mathbf{J 2 J 2} & \mathrm{AJ} 2 & \mathrm{NJ} 2 & \mathrm{NLJ} 2 & \mathrm{NRJ} 2 \\ \mathrm{~J} 1 \mathrm{~A} & \mathrm{~J} 2 \mathrm{~A} & \text { AA } & \text { NA } & \text { NLA } & \text { NRA } \\ \mathrm{J} 1 \mathrm{~N} & \mathrm{~J} 2 \mathrm{~N} & \text { AN } & \text { NN } & \text { NLN } & \text { NRN } \\ \mathrm{J} 1 \mathrm{NL} & \mathrm{J} 2 \mathrm{NL} & \text { ANL } & \text { NNL } & \text { NLNL } & \text { NRNL } \\ \mathrm{J} 1 \mathrm{NR} & \mathrm{J} 2 \mathrm{NR} & \text { ANR } & \text { NNR } & \text { NLNR } & \text { NRNR }\end{array}\right] \times\left[\begin{array}{l}t_{1} \mathrm{~J} 1 \\ t_{1} \mathrm{~J} 2 \\ t_{1} \mathrm{~A} \\ t_{1} \mathrm{~N} \\ t_{1} \mathrm{NL} \\ t_{1} \mathrm{NR}\end{array}\right]=\left[\begin{array}{l}t_{2} \mathrm{~J} 1 \\ t_{2} \mathrm{~J} 2 \\ t_{2} \mathrm{~A} \\ t_{2} \mathrm{~N} \\ t_{2} \mathrm{NL} \\ t_{2} \mathrm{NR}\end{array}\right]$

Fig. 3. Erioderma pedicellatum. Structure of the parameter matrix used to project a population of $E$. pedicellatum from time period $1\left(t_{1}\right)$ to time period $2\left(t_{2}\right)$ where $S$ is the survival rate and $P$ is the probability of moving from one life stage cohort to another. See 'Materials and methods' for codes for life stage cohorts (J1, J2, A, NL, NR)

1 to $>500$ and averaged 61 for sexually mature life stages, but variance was large and standard deviation generally exceeded the mean. Therefore, recruits were allocated to each apothecia-bearing life stage (Stages 3 to 6, A to $\mathrm{NR}_{i}$ see above) in proportion to their relative abundance in the study population. For example, if half of the apothecia-bearing thalli were NL, then half of the recruits were treated as having originated from this life stage. Furthermore, in our life stage model the J1 cohort was assumed to transition into J2 if it survived the field interval (approximately $6 \mathrm{mo}$ ); hence the J1 life stage lacks a self-loop. We also assumed that phorophytes on which E. pedicellatum was located would have the same probability of being colonized by recruits as other adjacent potential host trees. Hence, recruits in our study relate to those found on existing phorophytes already identified to be supporting E. pedicellatum. If previously undiscovered phorophytes were located during field visits, we included these new thalli into our demographic study. In over a decade of field investigations of $E$. pedicellatum we have been unable to detect recruitment and establishment of thalli in other age stands or in other parts of our study area.

\section{RESULTS}

\section{General demography}

Overall, Erioderma pedicellatum exhibited high adult survival and low recruitment (Table 1). We detected most transitions evidenced in the life stagestructured cycle diagram (Fig. 2), and the mean parameter matrix projected an annual decline of -0.1868 for the population (Table 2). The stable stage distribution assessment indicated that the current populations of E. pedicellatum in Newfoundland have more juveniles and less apothecia-bearing thalli (especially NL and NR) than projected (Table 3). The projected population growth rates indicated that both populations are declining $(\lambda<1.0)$, and the rate of decline was highest in spring to fall 2007 for Lockyer's Waters. The annual

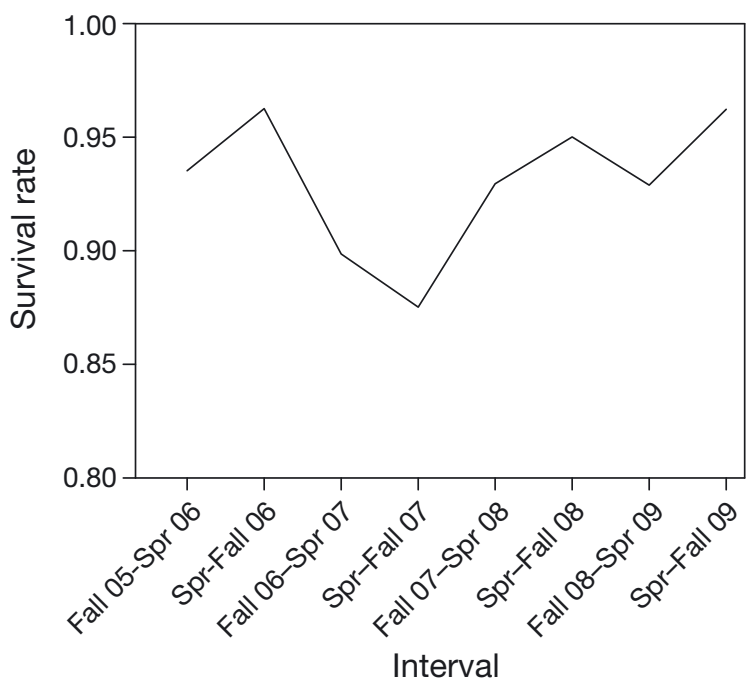

Fig. 4. Erioderma pedicellatum. Weighted mean survival of apothecia-producing thalli (grand mean $\pm \mathrm{SD}=0.930 \pm$ 0.031) at Lockyer's Waters, eastern Newfoundland, fall 2005 to fall 2009. Spr: spring

Table 1. Erioderma pedicellatum. Survival rates (in parentheses: no. of individual thalli) for life stage cohorts and recruitment of E. pedicellatum in the Lockyer's Waters study area, eastern Newfoundland for fall 2005 to fall 2009. Note that the fall 2005 Juvenile 1 cohort was not differentiated from Juvenile 2. Also, not all thalli were necessarily relocated

\begin{tabular}{|lcccccccc|}
\hline Life stage cohort & $\begin{array}{c}\text { Fall 2005- } \\
\text { spring } \\
2006\end{array}$ & $\begin{array}{c}\text { Spring- } \\
\text { fall 2006 }\end{array}$ & $\begin{array}{c}\text { Fall 2006- } \\
\text { spring } \\
2007\end{array}$ & $\begin{array}{c}\text { Spring- } \\
\text { fall 2007 }\end{array}$ & $\begin{array}{c}\text { Fall 2007- } \\
\text { spring } \\
2008\end{array}$ & $\begin{array}{c}\text { Spring- } \\
\text { fall 2008 }\end{array}$ & $\begin{array}{c}\text { Fall 2008- } \\
\text { spring } \\
2009\end{array}$ & $\begin{array}{c}\text { Spring- } \\
\text { fall 2009 }\end{array}$ \\
\hline Juvenile 1 & & $0.750(8)$ & $0.737(26)$ & $0.667(22)$ & $0.500(10)$ & $0.750(8)$ & $0.667(3)$ & $0.765(17)$ \\
Juvenile 2 & $0.676(74)$ & $0.897(58)$ & $0.930(46)$ & $0.880(30)$ & $0.905(21)$ & $0.750(12)$ & $0.750(5)$ & $1.000(10)$ \\
Adult & $0.971(68)$ & $1.000(60)$ & $0.943(63)$ & $0.925(59)$ & $0.824(34)$ & $0.952(84)$ & $0.906(51)$ & $0.984(83)$ \\
Necrotic & $0.923(27)$ & $0.944(36)$ & $0.913(51)$ & $0.837(50)$ & $0.928(69)$ & $0.964(55)$ & $0.916(61)$ & $0.956(57)$ \\
Necrotic loose & $0.951(61)$ & $0.947(94)$ & $0.885(139)$ & $0.864(146)$ & $0.934(106)$ & $0.929(126)$ & $0.923(105)$ & $0.947(112)$ \\
Necrotic regenerating & $0.833(30)$ & $0.958(24)$ & $0.960(27)$ & $0.892(37)$ & $0.983(60)$ & $1.000(35)$ & $0.962(78)$ & $0.966(76)$ \\
Recruitment & 11 & 21 & 13 & 13 & 7 & 5 & 17 & 3 \\
Recruitment (per adult) & $0.059(186)$ & $0.098(214)$ & $0.046(280)$ & $0.045(292)$ & $0.026(269)$ & $0.017(300)$ & $0.058(295)$ & $0.009(328)$ \\
\hline
\end{tabular}


Table 2. Erioderma pedicellatum. Mean parameter matrix $(M=\varnothing \times P$, where $\varnothing$ and $P$ are the estimated survival and transition rates, respectively, of life stages) for population model for fall to fall of life stage cohorts of $E$. pedicellatum in the Lockyer's Waters study area, eastern Newfoundland, 2005 to 2009. The average recruitment of Juvenile 1 was 12. n: no. of individual thalli

\begin{tabular}{|lcccccc|}
\hline \multirow{2}{*}{$\begin{array}{l}\text { Initial life stage } \\
\text { cohort (n) }\end{array}$} & \multicolumn{5}{c}{ Projected life stage cohort } \\
\cline { 2 - 6 } \cline { 3 - 6 } & Juvenile 1 & Juvenile 2 & Adult & Necrotic & Necrotic loose & \multirow{2}{*}{ Necrotic regenerating } \\
\hline Juvenile 1 (14) & 0 & 0.0817 & 0.1361 & 0.0856 & 0.0323 & 0.0086 \\
Juvenile 2 (32) & 0 & 0.0585 & 0.1453 & 0.1664 & 0.0719 & 0.0584 \\
Adult (63) & 0.0102 & 0.0019 & 0.1928 & 0.2753 & 0.2404 & 0.0830 \\
Necrotic (51) & 0.0083 & 0.0022 & 0.0751 & 0.2900 & 0.3134 & 0.1189 \\
Necrotic loose (112) & 0.0182 & 0.0061 & 0.0434 & 0.0978 & 0.5132 & 0.1485 \\
Necrotic regenerating (46) & 0.0075 & 0.0043 & 0.0663 & 0.0894 & 0.2224 & 0.4426 \\
\hline
\end{tabular}

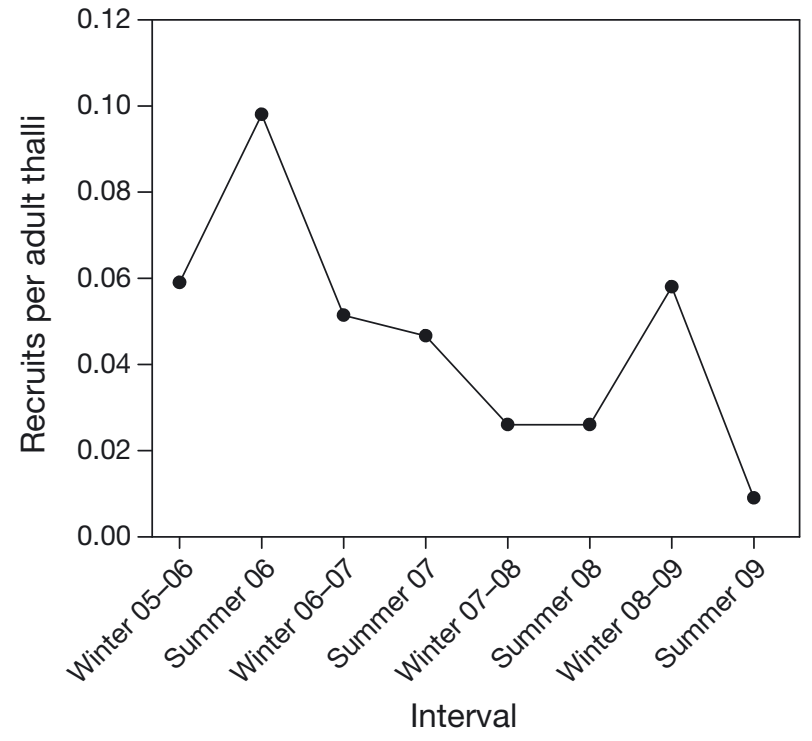

Fig. 5. Erioderma pedicellatum. Recruits per adult (mean \pm $\mathrm{SD}=0.045 \pm 0.028$ ) by winter and summer 2006 to 2009 for Lockyer's Waters study area, eastern Newfoundland $\left(F_{1,6}=5.033, \mathrm{p}=0.066, \mathrm{R}^{2}=0.456\right)$

projected declines from fall 2005 to fall 2009 at Lockyer's Waters were: $-0.1177,-0.2760,-0.1067$ and -0.1994 (mean \pm SD, $-0.175 \pm 0.079$ ) for 2005-2006, 2006-2007, 2007-2008 and 2008-2009, respectively (Table S1), and for Bay d'Espoir the annual projected decline from fall 2007 to fall 2008 was -0.1916 (Table 3).

A stochastic analysis was completed for the $4 \mathrm{yr}$ of data (fall 2005 to fall 2009) at Lockyer's Waters and indicated negative growth (mean $\pm \mathrm{SE}, \lambda=$ $0.8092 \pm 0.0132)$. The $95 \%$ confidence interval (0.7839-0.8357) did not encompass 1.0, providing clear support that the mean rate of decline of -0.1908 was valid. The mean \pm SD survival of apothecia-bearing adults for 2005 to 2009 was 0.930 \pm 0.031 (Fig. 4), and there were weak indications that recruits per adult may have declined over the study period (Fig.5).
Table 3. Erioderma pedicellatum. Actual and projected mean annual population size by life stage cohort of E. pedicellatum in the Lockyer's Waters study area of eastern Newfoundland for fall 2005 to fall 2009 and in the Bay d'Espoir study area of south-central Newfoundland for fall 2007 to fall 2008. Necrotic regen.: necrotic regenerating; Pop. growth: population growth

\begin{tabular}{|c|c|c|c|c|}
\hline \multirow[t]{2}{*}{ Life stage cohort } & \multicolumn{2}{|c|}{ Lockyer's Waters } & \multicolumn{2}{|c|}{ Bay d'Espoir } \\
\hline & Actual & Projected & Actual & Projected \\
\hline Juvenile 1 & 22 & 5 & 29 & 10 \\
\hline Juvenile 2 & 30 & 3 & 44 & 9 \\
\hline Adult & 59 & 30 & 79 & 33 \\
\hline Necrotic & 50 & 62 & 145 & 162 \\
\hline Necrotic loose & 146 & 155 & 126 & 226 \\
\hline Necrotic regen. & 37 & 89 & 108 & 91 \\
\hline Pop. growth $(\lambda)$ & & 0.8132 & & 0.9561 \\
\hline Recruits & 12 & & 31 & \\
\hline
\end{tabular}

The elasticity values based on the demographic rates in the Bay d'Espoir field data set indicated that the population growth rate was especially sensitive to changes in survival of $\mathrm{A}, \mathrm{N}$ and NL life stage cohorts, whereas in the Lockyer's Waters data set, population growth was most affected by the NL and NR cohorts (Table 4). The effect on population growth of a relative change in surviving and remaining in the NL cohort was approximately 1000 -fold more than the effect of the J2 stage cohort surviving.

\section{DISCUSSION}

Species that maintain population stability by means of high adult survival often stabilize in numbers near the carrying capacity $(K)$ of the environment (Minkoff 1983). Such species are sensitive to increased mortality and are more likely to become species at risk (Shaw 1985). The current stable stage distribution in Erioderma pedicellatum in our study area in Newfoundland was considerably different from the projected numbers. Our interpretation is that the present popula- 
Table 4. Erioderma pedicellatum. Elasticity matrix for transitions of life stage cohorts for E. pedicellatum in the Lockyer's Waters study area, eastern Newfoundland, based on the mean annual parameter matrix for fall 2005 to fall 2009 and Bay d'Espoir study area, south-central Newfoundland, for fall 2007 to fall 2008. The entire matrix sums to 1.00 and each value is the relative influence of the parameter on population growth $(\lambda)$. Bold indicates the dominating transitions influencing population growth rate

\begin{tabular}{|c|c|c|c|c|c|c|}
\hline \multirow{2}{*}{$\begin{array}{l}\text { Initial life stage } \\
\text { cohort (n) }\end{array}$} & \multirow[b]{2}{*}{ Juvenile 1} & \multirow[b]{2}{*}{ Juvenile 2} & \multirow{2}{*}{\multicolumn{2}{|c|}{$\begin{array}{l}\text { Projected life stage } \\
\text { Adult } \quad \text { Necrotic }\end{array}$}} & \multirow{2}{*}{$\begin{array}{l}\text { cohort } \\
\text { Necrotic loose }\end{array}$} & \multirow[b]{2}{*}{ Necrotic regenerating } \\
\hline & & & & & & \\
\hline \multicolumn{7}{|c|}{ Lockyer's Waters, fall 2005-fall 2008} \\
\hline Juvenile 1 & 0 & 0 & 0.0004 & 0.0007 & 0.0038 & 0.0009 \\
\hline Juvenile 2 & 0.0009 & 0.0003 & 0.0001 & 0.0003 & 0.0020 & 0.0008 \\
\hline Adult & 0.0025 & 0.0013 & 0.0200 & 0.0162 & 0.0236 & 0.0207 \\
\hline Necrotic & 0.0016 & 0.0015 & 0.0290 & 0.0634 & 0.0540 & 0.0283 \\
\hline Necrotic loose & 0.0006 & 0.0007 & 0.0258 & 0.0700 & 0.2893 & 0.0720 \\
\hline Necrotic regenerating & 0.0002 & 0.0006 & 0.0091 & 0.0272 & 0.0857 & 0.1466 \\
\hline \multicolumn{7}{|c|}{ Bay d'Espoir, fall 2007-fall 2008} \\
\hline Juvenile 1 & 0 & 0 & 0.0011 & 0.0026 & 0.0021 & 0.0005 \\
\hline Juvenile 2 & 0.0027 & 0.0034 & 0.0008 & 0.0037 & 0.0014 & 0.0004 \\
\hline Adult & 0.0022 & 0.0058 & 0.1286 & 0.0633 & 0.0359 & 0.0120 \\
\hline Necrotic & 0.0007 & 0.0018 & 0.0646 & 0.1446 & 0.0867 & 0.0282 \\
\hline Necrotic loose & 0.0005 & 0.0012 & 0.0407 & 0.0874 & 0.1621 & 0.0295 \\
\hline Necrotic regenerating & 0.0001 & 0.0001 & 0.0120 & 0.0251 & 0.0332 & 0.0150 \\
\hline
\end{tabular}

tion was derived from a different set of demographic rates, meaning there has been a shift in vital rates to the current unsustainable levels. We hypothesize that the current rates of population growth will not sustain the population beyond another couple of decades, i.e. future life expectancy $(Y)=0.5+[1 /(1-\varnothing)]$. Some thalli currently being monitored in eastern Newfoundland were located as adults in the mid-1990s and so are already more than 15 yr old. Maass \& Yetman (2002) noted that thalli of $E$. pedicellatum may survive through the over-mature to the decaying phase of the forest, from which could be inferred ages of at least 40 to 50 yr. Nevertheless, these wet balsam fir forests qualify as old-growth status (e.g. Thompson et al. 2003), and are more appropriately viewed as maintaining a full or partial canopy for long periods of time (centuries). The number of thalli declined in the Lockyer's Waters study area at a rate of -0.183 from 1997 to 2005 (R. I. Goudie \& E. Conway unpubl. data). Without some positive change in these vital rates, the population at Lockyer's Waters is likely to go extinct over the next few decades. The stochastic model developed corroborated the findings in the annual deterministic models. In part, this reflects that demographic rates are not exhibiting wide variation across years. Our preliminary findings support the idea that the disjunct population in Bay d'Espoir may also be declining, and that a declining pattern may apply to all the Newfoundland populations of this lichen.

The rapid decline of Erioderma pedicellatum in Lockyer's Waters is of concern because the area has been protected from logging and development since 1996. A number of factors could be contributing to this.
Blagden (1994) estimated that sulphate $\left(\mathrm{SO}_{4}\right)$ deposition in the Salmonier Nature Park, some $10 \mathrm{~km}$ northeast from the E. pedicellatum population, was approximately $10 \mathrm{~kg} \mathrm{ha}^{-1} \mathrm{yr}^{-1}$, which exceeds the buffering capacity of the region's lakes (RMCC 1990) and almost certainly that of balsam fir bark. The main local source of wet sulphate is the Holyrood Thermal Generating Plant (15 km to the northeast), which released $18400 \mathrm{t}$ $\mathrm{yr}^{-1}$ of $\mathrm{SO}_{2}$ in 1994. E. pedicellatum is considered highly sensitive to acid precipitation, which is hypothesized to be the cause of its rapid decline in Nova Scotia (Maass \& Yetman 2002).

In the Newfoundland study areas, thalli of E. pedicellatum are located almost entirely on balsam fir Abies balsamea, which is the main forage species for the large population (densities of 1 to 2 moose $\mathrm{km}^{-2}$ ) of introduced moose Alces alces. Currently there is little regeneration of balsam fir occurring in stands except close to roadways, ATV tracks, trails and accessible areas, where a limited annual hunt occurs. Moose colonized the Avalon Peninsula (Lockyer's Waters area) in the 1950s, and high densities were reached by the 1980s. Under current management regimes, moose harvest rates are kept low to maintain high hunter success, while large-scale clear-cutting is promoted. After forest harvesting, silviculture is also preventing balsam fir regeneration by using white spruce Picea glauca or exotic species resistant to herbivory (Department of Forest Resources and Agrifoods 2003). Under this forest management regime, white spruce is likely to replace balsam fir as the dominant and naturally occurring softwood cover (Meades \& Moores 1989). The ability of E. pedicellatum to colonize these planta- 
tions is unknown, although this lichen has occasionally been documented on white spruce, white birch Betula papyrifera and red maple Acer rubrum (Maass \& Yetman 2002).

Juvenile thalli of Erioderma pedicellatum may require a full range of structural diversity in the forest stands in order to establish (Scheidegger 1998, Ringius 1997). The scarcity of recruits over the $4 \mathrm{yr}$ of our study in part reflects a higher rate of mortality in the juvenile cohort. Our model predicted that the projected stable stage distribution should have proportionately fewer juveniles than we actually documented in the field. We interpret this to indicate that the populations are unsustainable because of adult mortality. This could be because of changes in the ecology of the over-mature balsam fir forests in Newfoundland that normally exhibit gap replacement from seedlings in the understory (Thompson et al. 2003). In recent decades, the gaps have not been regenerated by natural ecological forest types once collapse of decadent trees occurs. Large and old trees are often 'bearers' of biodiversity in boreal forests (Lie et al. 2009). These balsam fir forests conform to some of the criteria that indicate that they are 'old-growth', a key component of which is that there has been a continuous, full or partial canopy cover for centuries. This optimizes the biodiversity of epiphytic lichens as well as endemic oribatid mites, beetles and Collembola (Thompson et al. 2003). Invertebrates may be vectors of dispersal of E. pedicellatum and other rare lichens in these forested landscapes, as our field observations noted a high rate $(>0.75)$ of browsing by mites on thalli of E. pedicellatum. Thompson et al. (2003) noted that commercial clear-cuts exceeded the size of gaps left by natural disturbances, and thereby may prevent dispersal of microfauna.

Old growth balsam fir forests are also important to indicator species such as woodland caribou Rangifer tarandus, marten Martes americana and black-backed woodpeckers Picoides arcticus (Thompson et al. 2003). The forest management system in Newfoundland promotes the selective removal of over-mature forests (Department of Forest Resources and Agrifoods 2003), which in many cases would be synonymous with oldgrowth forests. Progressive loss of these lichen-rich forests and the inability of balsam fir to regenerate to fill gaps may be contributing to the rapid decline of Erioderma pedicellatum and other species, such as woodland caribou, that are dependent on them. We recommend that management be directed toward locating old-growth coniferous forests on insular Newfoundland in order to focus inventory and protection of their important biological diversity. Reduction of moose populations should be promoted through increased hunting quotas, and must be integrated with maintain- ing vigorous regeneration of balsam fir. In areas of core populations of $E$. pedicellatum it may be possible to establish exclosures, which would also support further scientific research into the influence of the natural forest ecology on population viability.

Acknowledgements. A number of additional individuals helped complete various components of the fieldwork. M. Drew, F. Hinks, A. Joe and C. Benoit of the Miawpukek First Nation were important in completing the project initiation and data collection in the area of Bay d'Espoir. A. Rao, C. Jones, E. Kissler and J. Croft helped collect field data in 2008. An earlier version of this manuscript was reviewed by L. Siegwart, and G. Robertson provided experienced guidance in the application and interpretations of population model outputs from Matlab $\bigodot^{\circ}$. We acknowledge support from the Newfoundland and Labrador Lichen Education and Research Group and the Swiss Federal Institute for Forest Snow and Landscape Research. The research was financially supported by the Voisey's Bay Nickel Corporation (grant to C.S. and E.C.), and Vale Inco Newfoundland and Labrador Limited (contract to LGL Limited Environmental Research Associates).

\section{LITERATURE CITED}

Ahlner S (1948) Utbredningstyper bland Nordiska barrträdslavar. Almquist \& Wiksells, Uppsala

Ahti T, Jørgensen P (1971) Notes on the lichens of Newfoundland. I. Erioderma boreale, new to North America. Bryologist 74:378-381

Blagden P (1994) Acid precipitation monitoring at Salmonier. In: Liverman D, Hall J (eds) The Salmonier drainage basin, Newfoundland: a focal for Terramon environmental monitoring and research. Centre for Earth Resources Research, Memorial University of Newfoundland, St. John's, NL, Canada, p 36-38

Cameron RP (2002) Habitat associations of epiphytic lichens in managed and unmanaged forest stands in Nova Scotia. Northeast Nat 9:27-46

Cameron RP, Neily T (2008) Heuristic model for identifying the habitats of Erioderma pedicellatum and other rare cyanolichens in Nova Scotia, Canada. Bryologist 111: 650-658

Caswell H (2001) Matrix population models: construction, analysis and interpretation, second edition. Sinauer Associates Inc., Sunderland, ME

Department of Forest Resources and Agrifoods (2003) Provincial Sustainable Forest Management Strategy 2003. Government of Newfoundland and Labrador, available at www.nr.gov.nl.ca/nr/forestry/manage/index.html

Fahselt D (1996) Individuals, populations and population ecology. In: Nash TH (ed) Lichen biology. Cambridge University Press, Cambridge, p 181-198

> Farrar JF (1974) A method for investigating lichen growth rates and succession. Lichenologist 6:151-155

Federal-Provincial Research and Monitoring Committee (RMCC) (1990) The 1990 Canadian long range transport of air pollutants and acid deposition report, Part 4: aquatic effects. Environment Canada, Ottawa

Fieberg J, Ellner SP (2001) Stochastic matrix models for conservation and management: a comparative review of methods. Ecol Lett 4:244-266 
Hill DJ (1981) The growth of lichens with special reference to the modeling of circular thalli. Lichenologist 13:265-287

Holien H, Gaarder G, Hapnes A (1995) Erioderma pedicellatum still present, but highly endangered in Europe. Graph Scr 7:79-84

Jørgensen PM (1990) Erioderma pedicellatum (Hue) P. M. Jorg.: Norway's most enigmatic plant? Blyttia 48:119-123

Keeping B, Hanel C (2006) A five-year (2006-2011) management plan for the boreal felt lichen (Erioderma pedicellatum) in Newfoundland and Labrador. Department of Environment and Conservation, Wildlife Branch, Corner Brook

Leslie PH (1945) On the uses of matrices in certain population mathematics. Biometrika 33:183-212

Lie MH, Arup U, Grytnes JA, Ohlson M (2009) The importance of host tree age, size and growth rate as determinants of epiphytic lichen diversity in boreal spruce forests. Biodivers Conserv 18:3579-3596

Maass W (1980) Erioderma pedicellatum in North America: a case study of a rare and endangered lichen. Proc NS Inst Sci 30:69-87

Maass W (1983) New observations on Erioderma in North America. Nord J Bot 3:567-576

Maass W, Yetman D (2002) COSEWIC status report on Erioderma pedicellatum in Canada. Committee on the Status of Endangered Wildlife in Canada, Ottawa

McDonald DB, Caswell H (1993) Matrix methods for avian demography. In: Power DM (ed) Current ornithology, Vol. 10. Plenum Press, New York, NY, p 139-185

Meades WJ, Moores L (1989) Forest site classification manual: a field guide to the Damman forest types of Newfoundland. FRDA Report 003, Forestry Canada and Department of Forestry and Agriculture, Newfoundland

Minkoff EC (1983) Evolutionary biology. Addison-Wesley Publishing Company, Reading, MA

Nash TH (1996) Photosynthesis, respiration, productivity, and growth. In: Nash TH (ed) Lichen biology. Cambridge University Press, Cambridge, p 88-120

Nelson P, Walton J, Roland C (2009) Erioderma pedicellatum (Hue) P.M.Jørg. new to the United States and western North America, discovered in Denali National Park and Preserve and Denali State Park. Evansia 26:19-23

Rheault H, Drapeau P, Bergeron Y, Esseen PA (2003) Edge effects on epiphytic lichens in managed black spruce forests of eastern North America. Can J Res 33: 23-32

Richardson DHS, Cameron RP (2004) Cyanolichens: their response to pollution and possible management strategies for their conservation in Northeastern North America. Northeast Nat 11:1-22

Scheidegger C (1998) Erioderma pedicellatum: a critically endangered lichen species. Species: Newsletter Species Survival Commission IUCN 1998:68-69

Scheidegger C (2003) Erioderma pedicellatum. In: IUCN (ed) 2008 IUCN Red List of Threatened Species. IUCN, Gland, available at www.iucnredlist.org

Scheidegger C, Wolseley PA, Thor G (ed) (1995) Conservation biology of lichenised fungi. Mitt Eidgenoess Forsch Wald Schnee Landschaft 70:1-173

Scheidegger C, Wolseley P, Landolt R (2000) Towards conservation of lichens. Forest Snow Landsch Res 75: $282-433$

Shaw JH (1985) Introduction to wildlife management. McGraw-Hill Book, Toronto

Sillet SC, McCune B, Peck JE, Rambo TR, Ruchty A (2000) Dispersal limitations of epiphytic lichens result in species dependent on old-growth forests. Ecol Appl 10: 789-799

$>$ Thompson ID, Larson DJ, Montevecchi WA (2003) Characterization of old 'wet boreal' forests, with an example from balsam fir forests of western Newfoundland. Environ Rev 11:S23-S46

Tønsberg T, Gauslaa Y, Haugan R, Holien H, Timdal E (1996) The threatened macrolichens of Norway: 1995. Sommerfeltia 23:1-258

> Werth S, Wagner HH, Gugerli F, Holderegger R, Csencsics D, Kalwu JM, Scheidegger C (2006a) Quantifying dispersal and establishment limitation in a population of an epiphytic lichen. Ecology 87:2037-2046

Werth S, Wagner HH, Holderegger R, Kalwij JM, Scheidegger $C$ (2006b) Effect of disturbances on the genetic diversity of an old-forest associated lichen. Mol Ecol 15: 911-921

Werth S, Gugerli F, Holderegger R, Wagner HH, Csencsics D, Scheidegger C (2007) Landscape-level gene flow in Lobaria pulmonaria, an epiphytic lichen. Mol Ecol 16: $2807-2815$

Submitted: May 25, 2009; Accepted: November 16, 2010

Proofs received from author(s): February 15, 2011
Editorial responsibility: Dave Hodgson,

University of Exeter, Cornwall Campus, UK 